\title{
CYP2C19 Inducer
}

National Cancer Institute

\section{Source}

National Cancer Institute. CYP2C19 Inducer. NCI Thesaurus. Code C155922.

Any substance capable of increasing the activity of cytochrome P450 2C19. 